кар: Изд-во Сыктывкарского университета, 2001. 88 с.

7. Arnold D.E. Ceramic theory and cultural process. Cambridge University Press. 1985. 268 p.

8. Arnold D.E. Ecology and ceramic production in an Andean community. New studies in Archaeology. Cambridge University Press. 1993. 278 p.

9. Arnold D.E. Social Change and the Evolution of Ceramic Production and Distribution in a Maya Community. Boulder: University Press of the Colorado. 2008. $351 \mathrm{p}$.

10. Barley N. Smaching Pots. Feats of Clay from Africa. London: British Museum Press. 1994. 168 p.

11. DeBoer W.R. and Lathrap D. The making and breaking of Shipibo-Conibo ceramics // Ethnoarchaeology: Implications of ethnography for archaeology. N-Y. Columbia University Press. 1979. P. 102-138.

12. Longacre W.A. Kalinga pottery, an ethnoarchaeological study // Pattern of the Past. Cambridge: Cambridge University Press. 1981. P. 49-66.

13. Posey S. Yemeni Pottery. London: British Museum Press. 1994. 64 p.

14. Reith $\mathrm{Ch}$. Comparison of three pottery villages in Shan State, Burma. The Journal of Burma Studies. Northern Illinois University. Vol. 1. 1997. P. 45-82.

15. Rice P.M. Pottery Analysis. A Sourcebook. Chicago and London: The University of Chicago Press. 1987. 559 p.
16. Rooney D.F. Folk Pottery in South-East Asia. Singapore: Oxford University Press. 1987. 74 p.

17. Rye O.S. Pottery technology. TaraxacumWashington. 1981. 150 p.

18. Saraswati B. Pottey-Making Cultures and Indian Civilization. New Delhi: Abhinav Publications. 1979. $178 \mathrm{p}$.

19. Степанов П.Д. Гончарство у мордвы // Записки Научно-исслед. Института при Совете министров Мордовской АССР. №9. История и археология. Саранск: Мордовское гос. издательство. 1947. С. 147 169.

20. Бобринский А.А. Гончарная технология как объект историко-культурного изучения // Актуальные проблемы изучения древнего гончарства (коллективная монография). Самара: Изд-во СамГПУ, 1999. C. 5-109.

21. Кирсанов Р.С. Гончарство населения Самарского Поволжья в конце XVII-XVIII вв. // Древнее гончарство: итоги и перспективы изучения. М.: ИА PAH. 2010. С. 153-185.

22. Бобринский А.А. Гончарство Восточной Европы. Источники и методы изучения. М.: Наука, 1978. 272 c.

23. Цетлин Ю.Б. Древняя керамика. Теория и методы историко-культурного подхода. М.: ИА РАН, 2012. 384 с.

(C) 2015

\title{
POTTERY PRODUCTION IN THE MORDOVIA DISTRICT: ETHNOGRAPHIC STUDY
}

\author{
Yu.B. Tsetlin, doctor of history science, leading research fellow, \\ Theory and Method Department \\ Institute of Archaeology Russian Academy of Sciences, Moscow (Russia)
}

\begin{abstract}
The paper tells about the results of systematization and analysis of ethnography data on pottery production in Mordovia district, collected by Alexander A. Bobrinsky in the beginning of 1960th during complete questionnaire work. There are 75 messages as from the potters themselves (very rare) as from their younger relatives, local school-teachers, and others. Then became clear that most of the local potters were Russian migrants (not the Mordovians) lived here from 17-18th centuries. Distribution the Russian pottery traditions destroyed the local Mordovian ones preserved only in traces. But the Russian potters in Mordovia had retained more archaic pottery traditions than the same potters resided in Russia. Just these traditions have a lot of interest to study. The author investigates the Mordovian pottery production through the system of Historical-and-Cultural approach according to the universal structure of pottery technology and the whole pottery production process as a field of the human culture.
\end{abstract}

Keywords: Mordovia; ethnography; pottery production; clay vessels; technology; firing; cultural traditions.

УДК 902/904

\section{ТЕХНИКО-ТЕХНОЛОГИЧЕСКИЙ АНАЛИЗ СИНТАШТИНСКОЙ КЕРАМИКИ КУРГАНА ХАЛВАЙ 3}

(C) 2015

И.В. Шевнина, научный сотрудник лаборатории археологических исследований Костанайский государственный университет, Костанай (Казахстан)

Аннотаиия. Статья посвящена технико-технологическому анализу синташтинской керамики кургана Халвай 3. Курган Халвай 3 находится на левом берегу тобольского рукава Каратамарского водохранилища (Костанайская область, Северный Казахстан), исследовался в течении полевых сезонов 2009-2010 гг. Тургайской археологической экспедицией. Диаметр сооружения 32 м включая ров, высота насыпи 1 м. Материалы кургана Халвай 3 относятся к разным археологическим периодам, но сооружен курган был в синташтинскую 

технологический анализ исходного сырья и формовочных масс керамики был проведен при помощи метода бинокулярной микроскопии и петрографического анализа. В качестве исходного сырья халвайские гончары использовали запесоченные, ожелезненные гидрослюдистые глины. Для замеса глиняного теста использовалось два рецепта формовочной массы: глина+дресва+навоз; глина+дресва. Среди технологических приемов при изготовлении сосудов зафиксировано использование донно-емкостного, емкостного начина, спиральнозонального, лоскутно-комковатого налепа, лоскутов, жгутов и шаблона. керамика кургана Халвай 3 (рецепты формовочных масс, технологические приемы при изготовлении сосудов) находит прямые аналогии в таких синташтинских памятниках Южного Урала, как поселения Аркаим, Устье и могильник Большекараганский.

Ключевые слова: синташтинские памятники, курган Халвай 3, синташтинская керамика, технико-технологический анализ синташтинской керамики.

Курган Халвай 3 находится на левом берегу тобольского рукава Каратамарского водохранилища (Костанайская область, Северный Казахстан), исследовался в течении полевых сезонов 2009-2010 гг. Тургайской археологической экспедицией. Диаметр сооружения 32 м включая ров, высота насыпи 1 м. Материалы кургана Халвай 3 относятся к разным археологическим периодам, но сооружен курган был в синташтинскую эпоху. Аналогии изученных погребений достаточно широки и связаны, прежде всего, с такими могильниками как Синташта [1], Кривое озеро [2], Танаберген II [3], Каменный Амбар-5 [4] Солнце II [5, с. 22-42], курган 25 Большекараганского могильника [6] . Предварительные результаты исследований данного кургана уже были опубликованы [7, c. $211-216 ; 8$, с. $39-50$; 9, с. $219-242 ; 10$, с. $143-150]$. Всего исследовано восемнадцать сосудов из пяти синташтинских ям (№1,3,6,8,9) и рва (рис.1).

Технико-технологический анализ исходного сырья и формовочных масс керамики был проведен при помощи метода бинокулярной микроскопии и петрографического анализа. Петрографический анализ выполнен в петрографической лаборатории отдела вещественного состава ОАО «Кустанайская поисково-съемочная экспедиция» петрографами О.В. Карзановой, Л.Н. Попковой. Кроме того, были проведены следующие опыты (микрометодом):

1) анализ с применением молибдена аммония (MoH4)2AmO4 показывает наличие или отсутствие фосфатов, при взаимодействии с карбонатосодержащим черепком дает желтый цвет;

2) анализ с соляной кислотой $\mathrm{HCl}$ показывает наличие или отсутствие карбоната.

В качестве исходного сырья халвайские гончары использовали запесоченные, ожелезненные (среди гидроокислов железа отмечены магнетит, гематит) гидрослюдистые глины (таб.1). Среди естественных примесей выделен кварц окатанный пылевидный (по большей части размером менее 0,01 м). Содержание кварца в черепке - 40-50\%. Кроме этого выделены полевые шпаты, асбест, эпидот, апатит. Необходимо отметить, что некоторые образцы керамики дали положительную реакцию на куприт, а это говорит о том, что используемая в качестве исходного сырья глина, находилась вблизи медного месторождения. Залежи медных руд в Тургайских степях известны только на западе и юге региона, при этом месторождения характеризуются небольшими размерами и линзо- видным характером [11, с.8]. Органика представлена карбонатными (известняковыми) включениями. Иногда, в очень маленьком количестве, присутствует фосфат (анализ с применением молибдена аммония (MoH4)2AmO4), но при этом необходимо отметить, что аналогичную реакцию на этот анализ мог дать апатит [12, с. 334].

Среди примесей во всех сосудах зафиксирована дресва (до 20\%), размером до 4 мм которая представлена талькосодержащими породами (таб.1) (рис.2: 1). Данная примесь добавлялась в качестве отощителя, для лучшей формуемости сосуда, усиления термостойкости сосуда (предотвращения растрескивания при обжиге) и для уменьшения усадки во время сушки [13, с. 24;]. Тальковые породы тяготеют к Южному Уралу, что, в свою очередь дает возможность предполагать происхождение примеси талька в халвайских сосудах именно с этого региона [11, с.8; 14, с. 27-39].

Кроме этого в глину добавлялся навоз животных. Навоз использовался для уменьшения усадки сосудов во время сушки, а также для повышения способности выдерживать механические нагрузки [15, с. 87]. Состав органики, определен в данном случае петрографами как карбонатно-фосфатный. О добавлении навоза говорят также и косвенные признаки, например, немногочисленные отпечатки шерсти и наличие пор (рис.2: 3).

Таким образом, для замеса глиняного теста халвайские гончары использовали два рецепта формовочной массы: 1) глина+дресва+навоз (89\%); 2) глина+дресва (11\%);

На основе технико-технологического анализа керамики, можно сказать, что при формообразовании сосудов использовались лоскуты, жгуты и шаблон. Выявлены емкостный (56\%) и донно-емкостный начины (28\%). Один сосуд изготовлен из куска глины. Полое тело конструировалось на шаблоне (89\%). Следы шаблона сосуда-основы хорошо фиксируются на внутренней поверхности сосуда (отпечатки орнамента) (89\%) (рис.2: 6). В одном случае на дне и придонной части сосуда имеются отпечатки от тканевой прокладки. Полое тело конструировалось несколькими способами: лоскутно-комковатым (28\%) и спирально-зональным $(44,4 \%)$ налепом из лоскутов в один (30\%) или два слоя (70\%) (рис.2, 4). У 83\% сосудов наблюдается перерыв в формовке (на что указывает перепад толщины стенок в месте перерыва в формовке сосуда. Зафиксировано два случая, когда 


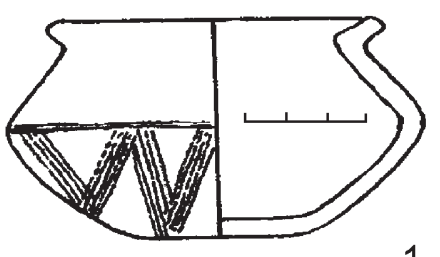

1

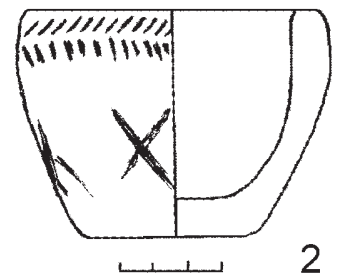

2
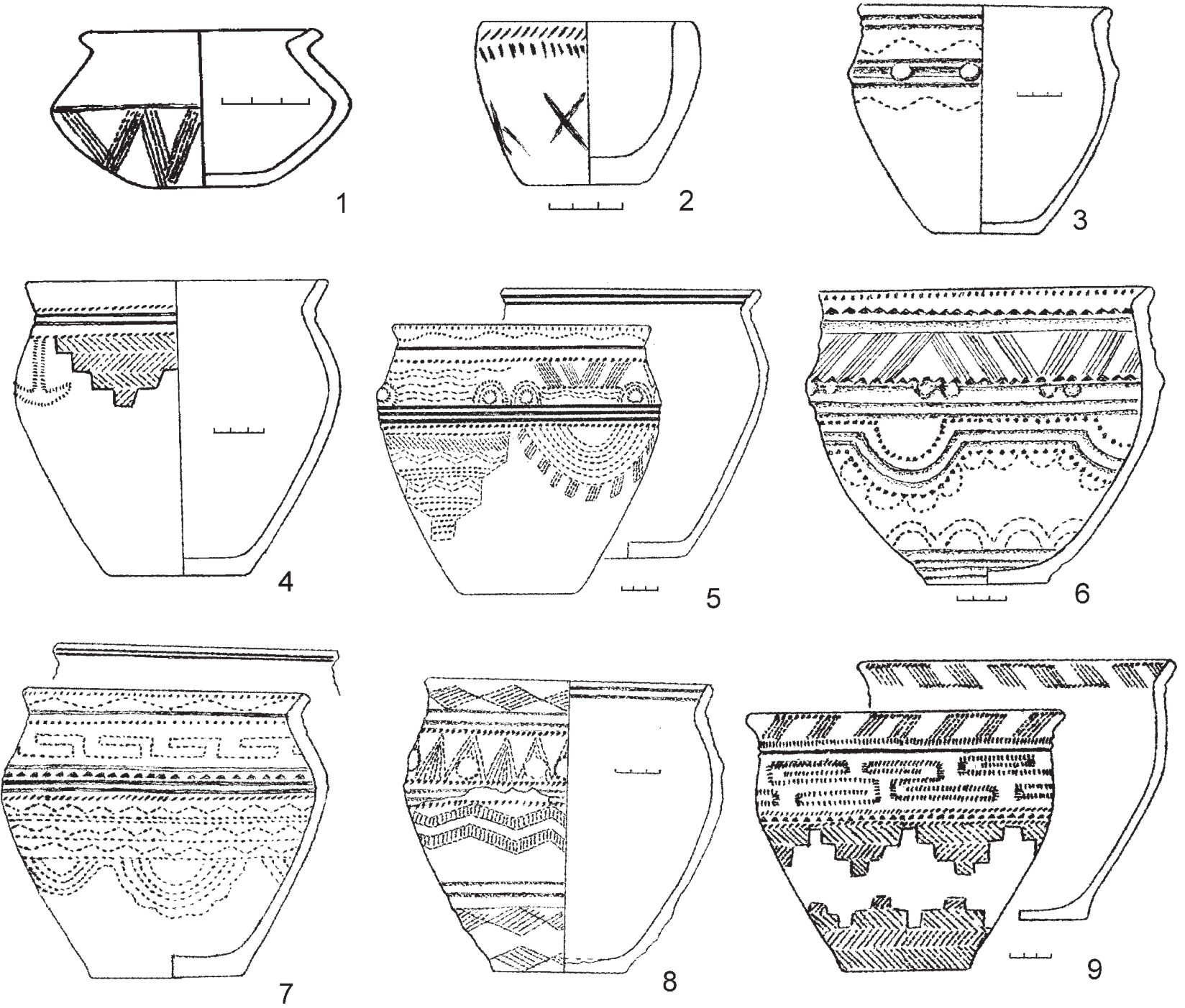

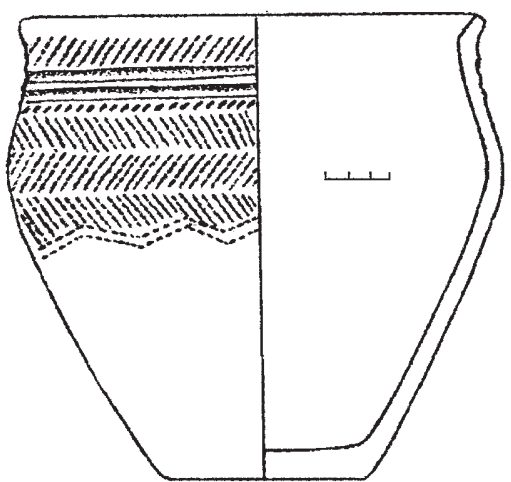

10
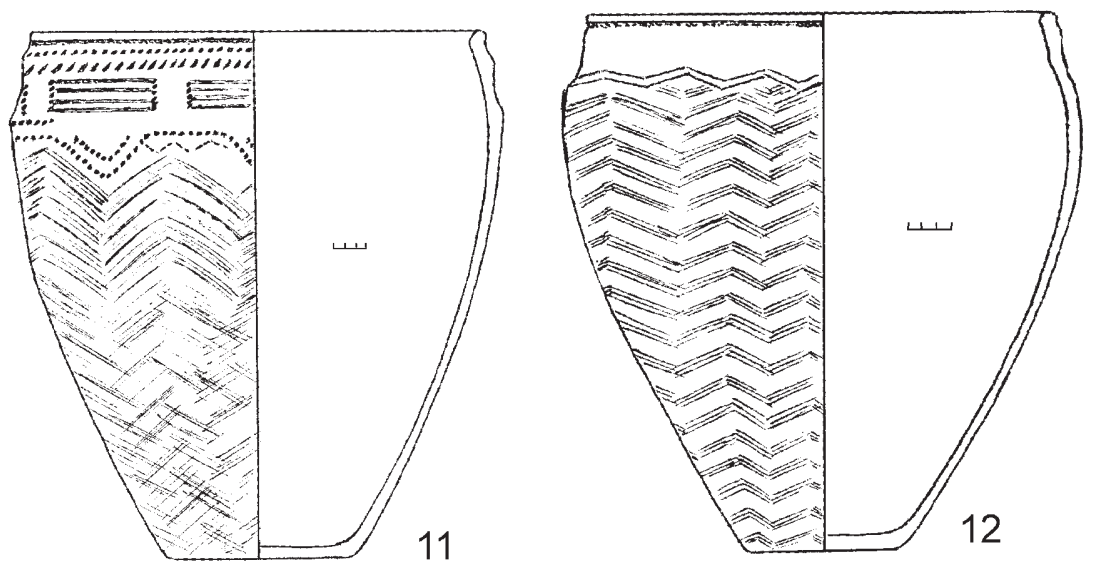

Рисунок 1 - Курган Халвай 3. Керамические сосуды.

нижняя часть выполнена на шаблоне, а верхняя часть лепилась без шаблона из жгутов (рис.2, 5) (нужно отметить, что в обоих случаях речь идет о сосудах крупных размеров (рис.1, 11,12). Дно чаще всего отмечено двойное (72\%), примазанное в два слоя лоскутов снаружи и изнутри сосуда (рис. 2: 2, 7).

Вся внешняя и частично внутренняя поверхность сосудов подвергалась лощению (до блеска) (89\%).
Данная процедура проводилась для придания сосудам большей водонепроницаемости [13, с. 57]. Также нужно отметить и декоративный эффект, так как у сосудов, имеющих в тесте примесь талька в сочетании с лощением, эффект блеска усиливается. Удалось зафиксировать макроследы - бороздчатые «канавки». Такие «канавки» возникают при лощении на подсушенной основе [16, с. 223]. Кроме этого 



1
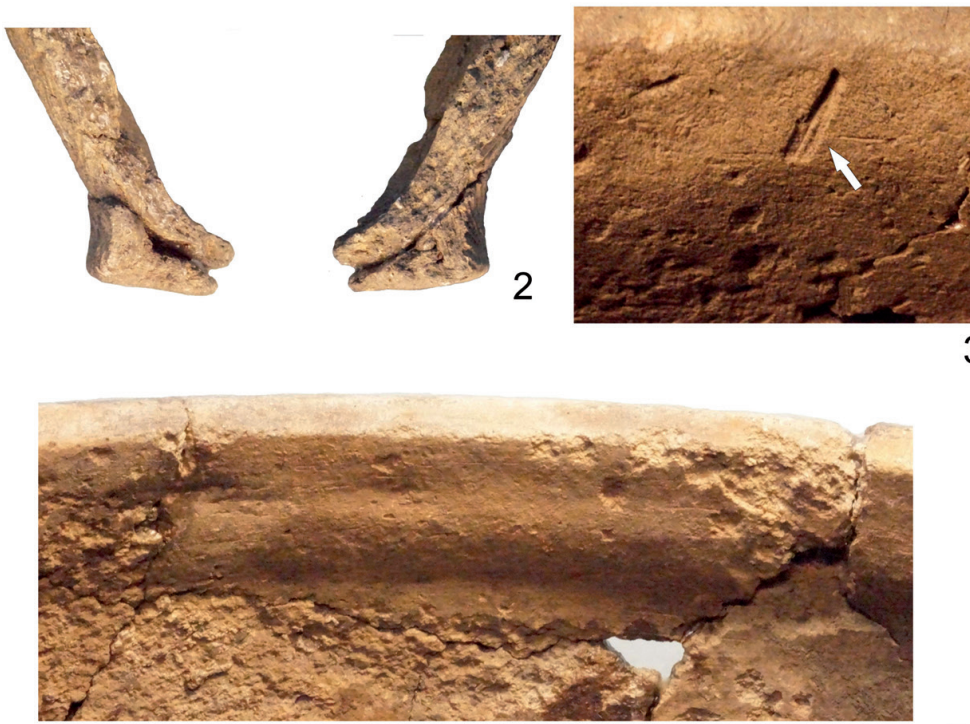

4

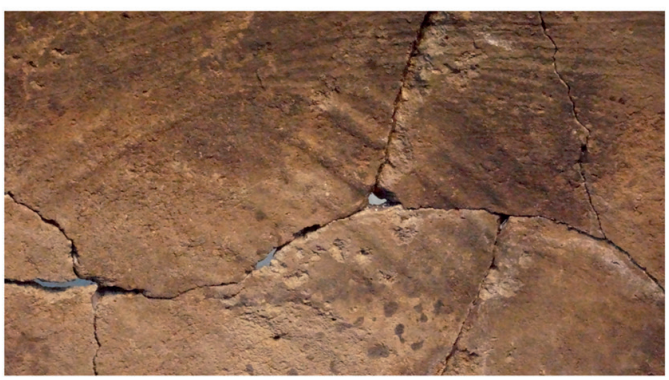

6
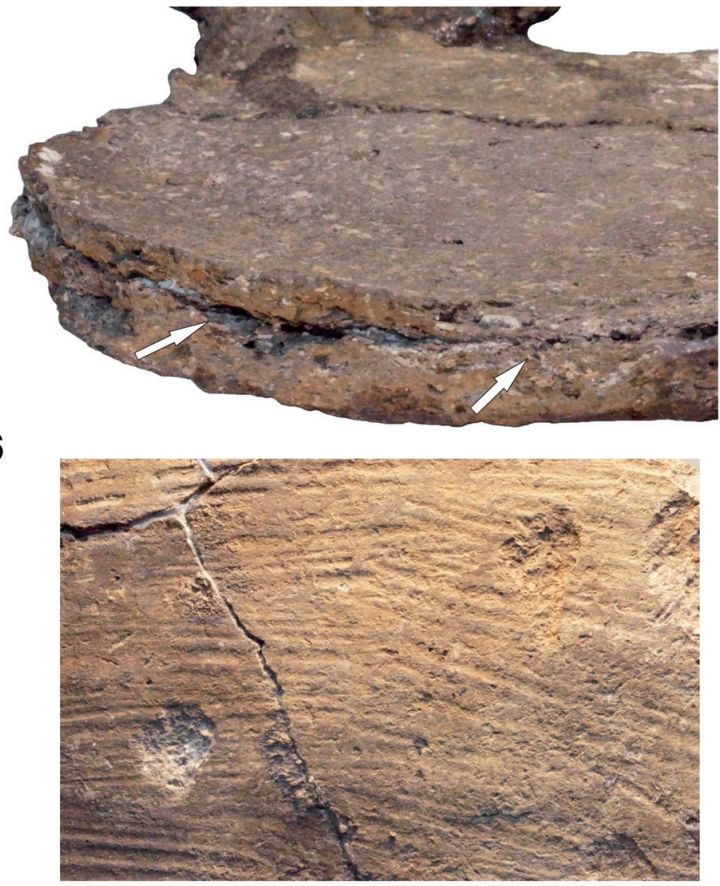

8

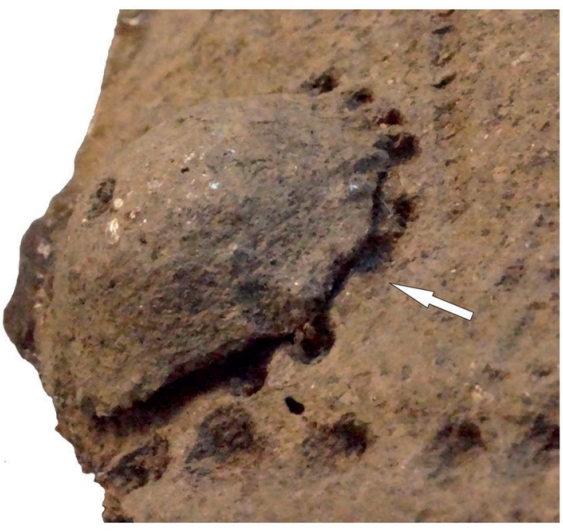

9

Рисунок 2 - Курган Халвай 3. Керамика.

1 - фрагмент керамики с включением дресвы из талькового сланца; 2 - «двойное дно»; 3 - фрагмент керамики с выгоревшим навозом; 4 - формовка в два слоя; 5 - рельеф жгута; 6 - орнамент на внутренней поверхности сосуда от сосуда-основы при формовке на шаблоне; 7 - «двойное дно»; 8 - налепной валик; 9 - заглаживание зубчатым штампом внутренней поверхности сосуда; 10 - подготовка к креплению «шишечек»; 11 - вдавления по окружности «шишечек», как технологический и декоративный прием. 
внутренняя поверхность сосудов заглаживалась зубчатым штампом (33\%) (рис.2: 9) или деревянным инструментом (17\%).

При исследовании халвайской керамики были зафиксированы налепные элементы декорирования сосудов: «шишечки» и валик (рис.2: 8). «Шишки» сформованы отдельно из маленьких кусочков глины, примазаны после нанесения узора. Место крепления «шишек» предварительно уплотнялось вдавлениями или насечками (рис.2: 10), затем примазывалась «шишечка» и дополнительно уплотнялась вдавлениями, по окружности. В данном случае вдавления выступают и как технологический прием и как элемент декорирования (рис.2: 11).

Сушка сосуда протекала в рациональном режиме. Информацию о сушке мы получили по контуру и форме пор. Петрографический анализ показал их округлую форму с естественным контуром, что указывает на то, что вода постепенно удалялась из пор сосуда [13, с. 80-81]. Цветовая характеристика сосудов указывает на восстановительный и окислительно-восстановительный обжиг.

В заключении отметим, что керамические сосуды кургана Халвай 3 (рецепты формовочных масс, технологические приемы при изготовлении сосудов) находит прямые аналогии среди синташтинской керамики таких памятников Южного Урала, как могильник Большекараганский, поселениях Аркаим, Устье и Мочище $[17$, с. $135-145 ; 18$, с. 132-135; 19 , c. $117-195 ; 20$, c. $179-184 ; 21$, c. $40-43]$.

\section{СПИСОК ЛИТЕРАТУРЫ:}

1. Генинг В.Ф., Зданович Г.Б., Генинг В.В. Синташта. Челябинск: Юж-Урал. кн. изд-во, 1992. 408 с.

2. Виноградов Н.Б. Могильник бронзового века Кривое Озеро в Южном Зауралье. Челябинск: ЮжУрал. кн. изд-во, 2003. 362 с.

3. Ткачев В.В. Степи Южного Приуралья и Западного Казахстана на рубеже эпох средней и поздней бронзы. Актобе: Актюбин. обл. центр истории, этнографии и археологии, 2007. 384 с.

4. Епимахов А.В. Ранние комплексные общества севера Центральной Евразии (по материалам могильника Каменный Амбар-5). Кн. 1. Челябинск: Челябинский дом печати, 2005. 190 с.

5. Епимахов А.В. Курганный могильник Солнце II - некрополь укрепленного поселения Устье эпохи средней бронзы // Материалы по археологии и этнографии Южного Урала. Челябинск: Каменный пояс, 1996. С. 22-42.

6. Зданович Д.Г. Археология кургана 25 Большекараганского могильника // Аркаим: Некрополь (по материалам кургана 25 Большекараганского могильника). Кн. 1. Челябинск: Юж-Урал. кн. изд-во, 2002. C. 17-105.

7. Логвин А.В., Шевнина И.В. Курган Халвай 3 (предварительное сообщение) // Маргулановские чтения - 2011. Астана: Сарыарка, 2011. С. 291-296.
8. Шевнина И.В., Логвин А.В. О реконструкции крепления бронзовых и каменных изделий к рукоятям и древкам (по материалам синташтинского кургана Халвай 3) // Этнические взаимодействия на Южном Урале: сб. науч.тр. отв.ред.: А.Д. Таиров, Н.О Иванова. Челябинск: Рифей, 2013. С. 39-50.

9. Логвин А.В., Шевнина И.В. Погребения эпохи развитой бронзы кургана Халвай 3 // Prehistory studies. Pontic area. Mangalia:»Callasprint», 2014. C. 219-242.

10. Шевнина И.В., Логвин А.В. Синташтинские курганы в Северном Казахстане (по материалам халвайских курганов // Процесс культурогенеза начальной поры позднего бронзового века Волго-Уральского региона (вопросы хронологии, периодизации, историографии): материалы международной научной конференции. 12-14 мая 2014 года. Самара: Изд-во ПГСГА, 2014. С.143-150.

11. Ким Ю.И. Полезные ископаемые // Экологический атлас Костанайской области. Костанай: Костанайполиграфия, 2004. С. 7-8.

12. Смолянинов Н.А. Практическое руководство по минералогии. М.: Госгеолтехиздат, 1955. 430 с.

13. Глушков И. Г. Керамика как археологический источник. Новосибирск: ИАЭ СО РАН, 1996. 327 с.

14. Левит А.И. Южный Урал: география, экология, природопользование. Челябинск: Юж.Урал. кн. изд-во, 2001. 145c.

15. Бобринский А.А. Гончарная технология, как объект историко-культурного изучения // Актуальные проблемы изучения древнего гончарства (коллективная монография). Самара: Изд-во СамГПУ, 1999. С. 5-109.

16. Бобринский А.А. Гончарство Восточной Европы. Источники и методы изучения. М.: Наука, 1978. $272 \mathrm{c}$.

17. Гутков А.И. Техника и технология изготовления керамики поселения Аркаим // Аркаим: исследования. Поиски. Открытия / науч. ред. Г.Б. Зданович; сост. Н.О. Иванова. Челябинск: Каменный пояс, 1995. С. 135-146.

18. Гутков А.И. Технология изготовления керамики памятников синташтинского типа // Россия и Восток: проблемы взаимодействия. Ч.V. Кн.2. Челябинск: Издво ЧелГу, 1995. С.132-135.

19. Гутков А.И. Техника и технология изготовления керамики кургана 25 Большекараганского могильника (таблицы) // Аркаим: некрополь (по материалам кургана 25 Большекараганского могильника). Кн.1 / сост. Д.Г. Зданович. Челябинск: Юж.-Урал. кн. изд-во, 2002. С. $117-118$.

20. Гутков А.И. Технико-технологический анализ керамики поселения Устье I // Древнее Устье: укрепленное поселение бронзового века в Южном Зауралье: коллект. моногр. / отв.ред. Н.Б.Виноградов; науч.ред. А.В. Епимахов. Челябинск: Изд-во «Абрис», 2013. C. 179-184.

21. Григорьев С.А., Петрова Л.Ю., Салугина Н.П. Типология и технология изготовления керамики поселения эпохи поздней бронзы Мочище в Южном Зауралье // Известия Челябинского научного центра, 2009. Вып. 2 (44). С. 40-43. 
И.В. Шевнина

ТЕХНИКО-ТЕХНОЛОГИЧЕСКИЙ АНАЛИЗ СИНТАШТИНСКОЙ КЕРАМИКИ...

Таблица 1 - Курган Халвай 3. Петрографические шлифы.

\begin{tabular}{|c|c|c|c|c|c|c|c|c|c|}
\hline $\begin{array}{l}\text { № } \\
\Pi / \Pi\end{array}$ & \begin{tabular}{|l|} 
Место \\
взятия \\
образца
\end{tabular} & $\begin{array}{l}\text { Фракционный } \\
\text { состав, \% (мм } \\
\text {-\%) }\end{array}$ & $\begin{array}{l}\text { Качественный со- } \\
\text { став песка, \% }\end{array}$ & $\begin{array}{l}\text { Состав формо- } \\
\text { вочной массы }\end{array}$ & $\begin{array}{l}\text { Природа } \\
\text { цемента }\end{array}$ & \begin{tabular}{|l|} 
Содер- \\
жание \\
дресвы, \%
\end{tabular} & $\begin{array}{l}\text { Размер } \\
\text { дресвы }\end{array}$ & $\begin{array}{l}\text { Объем } \\
\text { пор, \% }\end{array}$ & $\begin{array}{l}\text { Органические } \\
\text { примеси, } \\
\text { размер }\end{array}$ \\
\hline 1 & $\begin{array}{l}\text { Халвай-3. } \\
\text { Яма 1, } \\
\text { образец } \\
\text { шлиф 1 }\end{array}$ & $\begin{array}{l}\text { менее } 0,01- \\
30 \% \\
0,01-0,1-10 \% \\
0,1-0,25-10 \% \\
0,25-0,5-12 \% \\
0,5-1,0-12 \% \\
1,0-1,5-10 \% \\
1,5-2,0-10 \% \\
2,0-2,5-3 \% \\
2,5-3,0-3 \%\end{array}$ & $\begin{array}{l}\text { кварц - 40\% } \\
\text { полевых шпатов } \\
\text { - 3\% } \\
\text { остальные: } 54 \% \\
\text { магнетит - 4-5\% } \\
\text { гематит - до 3\% } \\
\text { асбест? - 1\% }\end{array}$ & $\begin{array}{l}\text { глина + дресва } \\
\text { + органика } \\
\text { фосфат. типа (в } \\
\text { составе дресвы } \\
\text { слюдисто-таль- } \\
\text { ковые сланце- } \\
\text { вые породы) }\end{array}$ & $\begin{array}{l}\text { гидрослюды } \\
\text { с примесью } \\
\text { органики и } \\
\text { гидроокислов } \\
\text { железа. } \\
\text { Куприт. }\end{array}$ & до 20\% & $\begin{array}{l}\text { до } 4 \text { мм, } \\
\text { в основ- } \\
\text { ном } 2,5 \mathrm{x} \\
0,8 \text { мм }\end{array}$ & до $5 \%$ & $\begin{array}{l}\text { Полидетрито- } \\
\text { вый, размер } \\
\text { тонкий, состав } \\
\text { фосффатный }\end{array}$ \\
\hline 2 & $\begin{array}{l}\text { Халвай-3. } \\
\text { Яма 1, } \\
\text { образец } \\
\text { шлиф 2 }\end{array}$ & $\begin{array}{l}\text { менее } 0,01- \\
28 \% \\
0,01-0,1-30 \% \\
0,1-0,25-10 \% \\
0,25-0,5-10 \% \\
0,5-1,0-3 \% \\
1,0-1,5-4 \% \\
1,5-2,0-5 \% \\
2,0-2,5-5 \% \\
2,5-3,0-5 \%\end{array}$ & $\begin{array}{l}\text { кварц - 40\%, } \\
\text { гематит - 10\% } \\
\text { магнетит, гематит - } \\
\text { до } 10 \% \\
\text { полевые шпаты } \\
\text { - зн. }\end{array}$ & $-11-$ & $-11-$ & $15 \%$ & до 3 мм & до 5\% & $-1 /-$ \\
\hline 3 & $\begin{array}{l}\text { Халвай-3. } \\
\text { Яма 1, } \\
\text { образец } \\
\text { шлиф 3 }\end{array}$ & $\begin{array}{l}\text { менее } 0,01- \\
33 \% \\
0,01-0,1-10 \% \\
0,1-0,25-20 \% \\
0,25-0,5-12 \% \\
0,5-1,0-10 \% \\
1,0-1,5-15 \% \\
1,5-2,0-3 \mathrm{H}\end{array}$ & $\begin{array}{l}\text { кварц 40\% } \\
\text { гематит, магнетит - } \\
\text { до 10\% } \\
\text { обломки полевых } \\
\text { шпатов - } 1 \% \\
\text { остальное - } 46 \% \\
\text { обломки сланцев, } \\
\text { кремня, кварцитов }\end{array}$ & \begin{tabular}{|l|}
\multicolumn{1}{|c|}{- // - } \\
дополнительно \\
в составе дрес- \\
вы серпентинит \\
- тальковые \\
обломки по- \\
род, прочие \\
значительно \\
измененные \\
аналогично \\
образцу 2
\end{tabular} & $-1 /-$ & $12-14 \%$ & $\begin{array}{c}\text { до } 1,5-2,0 \\
\text { MM }\end{array}$ & до $3-4 \%$ & $-11-$ \\
\hline 4 & $\begin{array}{l}\text { Халвай-3. } \\
\text { Ров, об- } \\
\text { разец } 1\end{array}$ & $\begin{array}{l}\text { менее } 0,01- \\
40 \% \\
0,01-0,1-10 \% \\
0,1-0,25-5 \% \\
0,25-0,5-30 \% \\
0,5-1,0-5 \% \\
1,0-1,5-10 \% \\
1,5-2,0-5 \%\end{array}$ & $\begin{array}{l}\text { аналогично образцу } \\
3 \text { ямы 1, } \\
\text { дополнительное со- } \\
\text { держание (куприта } \\
\text { - рыхлый, медный } \\
\text { минерал до } 2 \text { - } 5 \text { \%) }\end{array}$ & $\begin{array}{l}\text { аналогично об- } \\
\text { разцу } 3 \text { ямы } 1 \\
\text { окраска дресвы } \\
\text { и слюдисто- } \\
\text { тальковых } \\
\text { пород более } \\
\text { насыщена. } \\
\text { Это связано с } \\
\text { содержанием } \\
\text { красного цвета } \\
\text { куприта. }\end{array}$ & $\begin{array}{l}\text { гидрослюда } \\
\text { с примесью } \\
\text { органики, } \\
\text { значительно } \\
\text { ожелезненных } \\
\text { пигментов (ги- } \\
\text { дроокислов) } \\
\text { с купритом), } \\
\text { реакция на } \\
\text { медь положи- } \\
\text { тельная }\end{array}$ & до $12-15 \%$ & $\begin{array}{c}\text { до } 2 \mathrm{Mм} \\
\quad и \leq\end{array}$ & до $10 \%$ & \begin{tabular}{l}
\multicolumn{1}{c}{ - // - } \\
реакция на \\
фосфф. слабая
\end{tabular} \\
\hline 5 & $\begin{array}{l}\text { Халвай-3. } \\
\text { яма 3, } \\
\text { образец } \\
\text { шлиф 1 }\end{array}$ & $\begin{array}{l}\text { менее } 0,01- \\
45 \% \\
0,01-0,1-12 \% \\
0,1-0,25-20 \% \\
0,25-0,5-17- \\
18 \% \\
0,5-1,0-1 \% \\
1,0-1,5-1 \% \\
1,5-2,0-\text { - } \% \\
1-2 \%\end{array}$ & \begin{tabular}{|l} 
кварц - 50\% \\
кристобалит -30\% \\
карбонат - 1\% \\
полевые шпаты \\
$-3 \%$ \\
апатит - зн \\
эпидот - ед. зн \\
гидроокислы \\
железа \\
магнетит
\end{tabular} & $\begin{array}{l}\text { глина + дресва } \\
\text { (в составе дрес- } \\
\text { вы кремнисто- } \\
\text { фосф. органики } \\
\text { (спонголиты) }\end{array}$ & $\begin{array}{l}\text { гидрослюды } \\
\text { с примесью } \\
\text { органики и } \\
\text { гидроокислов } \\
\text { железа }\end{array}$ & до $10 \%$ & $1,5-2 \mathrm{MM}$ & до $7 \%$ & $\begin{array}{l}\text { кремнисто- } \\
\text { фосфратного } \\
\text { состава }\end{array}$ \\
\hline 6 & $\begin{array}{l}\text { Халвай-3. } \\
\text { Яма 3, } \\
\text { образец } \\
\text { шлиф 2 }\end{array}$ & $\begin{array}{l}\text { менее } 0,01- \\
45 \% \\
0,01-0,1-14 \% \\
0,1-0,25-18 \% \\
0,25-0,5-18 \% \\
0,5-1,0-1 \% \\
1,0-1,5-1 \% \\
1,5-2,0-1-2 \%\end{array}$ & $\begin{array}{l}\text { состав аналогичный } \\
\text { образцу } 1 \text { ямы } 3, \\
\text { дополнительно } \\
\text { окислы марганца } \\
\text { - зн } \\
\text { полевых шпатов - } \\
\text { до 1\% } \\
\text { магнетит, гематит, } \\
\text { гидроокислы желе- } \\
\text { за - до } 3 \text { - 5\% }\end{array}$ & $\begin{array}{l}\text { состав анало- } \\
\text { гичен образцу } 1 \\
\text { ямы } 3\end{array}$ & $-1 /-$ & до $10 \%$ & до 1,5 мм & до $10 \%$ & $-1 /-$ \\
\hline
\end{tabular}




\begin{tabular}{|c|c|c|c|c|c|c|c|c|c|}
\hline 7 & $\begin{array}{l}\text { Халвай-3. } \\
\text { Яма 3, } \\
\text { образец } \\
\text { шлиф } 3\end{array}$ & \begin{tabular}{|l} 
менее $0,01-$ \\
$45 \%$ \\
$0,01-0,1-14 \%$ \\
$0,1-0,25-20 \%$ \\
$0,25-0,5-16 \%$ \\
$0,5-1,0-1 \%$ \\
$1,0-1,5-2 \%$ \\
$1,5-2,0-2 \%$ \\
$2,0-2,5-3 \mathrm{H}$ \\
$2,5-3,0-3 \mathrm{H}$
\end{tabular} & $\begin{array}{l}\text { кварц до 50\% } \\
\text { аналогичный со- } \\
\text { став образца } 1 \text { ямы } \\
3 \text { дополнительно } \\
\text { карбонатно-слюди- } \\
\text { стые сланцы }\end{array}$ & $\begin{array}{l}\text { глина + дресва } \\
+ \text { органика } \\
\text { дополнительно } \\
\text { отмечается } \\
\text { присутствие } \\
\text { карбоната в со- } \\
\text { ставе дресвы }\end{array}$ & \begin{tabular}{|l}
- - /l- \\
цемент \\
участками \\
алевритистый \\
с пелита- \\
морфным \\
веществом, \\
значительно \\
ожелезненны- \\
ми участками
\end{tabular} & до $10 \%$ & $\begin{array}{l}\text { до } 2 \times 2 \\
\text { мм } и \leq\end{array}$ & до 8\% & $\begin{array}{l}\text { фосфата } \\
\text { очень мало, } \\
\text { органические } \\
\text { примести } \\
\text { кремнисто- } \\
\text { карбонатного } \\
\text { состава }\end{array}$ \\
\hline 8 & $\begin{array}{l}\text { Халвай-3. } \\
\text { Яма 3, } \\
\text { образец } \\
\text { шлиф } 4\end{array}$ & \begin{tabular}{|l} 
менее $0,01-50 \%$ \\
$0,01-0,1-20 \%$ \\
$0,1-0,25-6 \%$ \\
$0,25-0,5-6 \%$ \\
$0,5-1,0-13 \%$ \\
$1,0-1,5-4 \%$ \\
$1,5-2,0-1 \%$
\end{tabular} & $\begin{array}{l}\text { кварц - до 60\% } \\
\text { магнетит, гематит - } \\
\text { до 10\% } \\
\text { много гидроокислов } \\
\text { железа с эпидотом } \\
\text { во включениях } \\
\text { карбонат тонко } \\
\text { распылен }\end{array}$ & $\begin{array}{l}\text { - // - } \\
\text { в дресве наблю- } \\
\text { даются участки } \\
\text { талька и } \\
\text { гидрослюд (об- } \\
\text { ломки сланцев } \\
\text { с карбонатным } \\
\text { кварцем и } \\
\text { значительные } \\
\text { включения } \\
\text { рудных) }\end{array}$ & $-11-$ & до 5-7\% & $\begin{array}{l}\text { до } 1,5 \text { мм } \\
\text { редко } 2 \times 1 \\
\text { мм }\end{array}$ & до $10 \%$ & $-1 /-$ \\
\hline 9 & $\begin{array}{l}\text { Халвай-3. } \\
\text { Яма 3, } \\
\text { образец } \\
\text { шлиф } 5\end{array}$ & $\begin{array}{l}\text { менее } 0,01-30 \% \\
0,01-0,1-30 \% \\
0,1-0,25-5 \% \\
0,25-0,5-6 \% \\
0,5-1,0-13 \% \\
1,0-1,5-10 \% \\
1,5-2,0-6 \%\end{array}$ & $\begin{array}{l}- \text { - // - } \\
\text { дополнительно } \\
\text { апатит }\end{array}$ & $\begin{array}{l}\text { глина + дресва } \\
\text { + органика ана- } \\
\text { логично как в } \\
\text { шлифе образца } \\
4 \text { ямы } 3\end{array}$ & $\begin{array}{l}\text { - // - } \\
\text { аналогично } \\
\text { как в шлифах } \\
\text { образцов } 4 \text { и } 3 \\
\text { ямы } 3\end{array}$ & до 15\% & $\begin{array}{l}1,5 \times 1 \\
\text { мм редко } \\
\text { до } 2-4 \\
\text { мм }\end{array}$ & $10 \%$ & $\begin{array}{l}\text { аналогично } \\
\text { как в шлифе } \\
\text { образца } 4 \\
\text { ямы } 3\end{array}$ \\
\hline 10 & $\begin{array}{l}\text { Халвай-3. } \\
\text { Яма 3, } \\
\text { образец } \\
\text { шлиф } 6\end{array}$ & $\begin{array}{l}\text { менее } 0,01- \\
30 \% \\
0,01-0,1-30 \% \\
0,1-0,25-5 \% \\
0,25-0,5-6 \% \\
0,5-1,0-13 \% \\
1,0-1,5-10 \% \\
1,5-2,0-6 \%\end{array}$ & $\begin{array}{l}\text { Описание образца } \\
\text { аналогично шлифу } \\
\text { образца } 5 \text { ямы } 3\end{array}$ & $\begin{array}{l}\text { Описание } \\
\text { образца анало- } \\
\text { гично шлифу } \\
\text { образца } 5 \text { ямы } 3\end{array}$ & $\begin{array}{l}\text { Описание } \\
\text { образца } \\
\text { аналогично } \\
\text { шлифу образ- } \\
\text { ца } 5 \text { ямы } 3\end{array}$ & $\begin{array}{l}\text { Описание } \\
\text { образца } \\
\text { аналогич- } \\
\text { но шлифу } \\
\text { образца } 5 \\
\text { ямы } 3\end{array}$ & $-11-$ & $-11-$ & $-11-$ \\
\hline 11 & $\begin{array}{l}\text { Халвай-3. } \\
\text { Яма 5, } \\
\text { образец } \\
\text { шлиф } 1\end{array}$ & $\begin{array}{l}\text { менее } 0,01- \\
50 \% \\
0,01-0,1-20 \% \\
0,1-0,25-10 \% \\
0,25-0,5-7 \% \\
0,5-1,0-5 \% \\
1,0-1,5-3 \% \\
1,5-2,0-5 \%\end{array}$ & \begin{tabular}{|l} 
кварц - 60\% \\
плагиоклаз - 20\% \\
магнетит, гематит - \\
до $20 \%$ \\
сланцы - ост \\
(обломки) прочее
\end{tabular} & $\begin{array}{l}\text { глина +дресва } \\
\text { + органика (в } \\
\text { составе дресвы } \\
\text { перекристалл. } \\
\text { сланцы) }\end{array}$ & $\begin{array}{l}\text { гидрослюды } \\
\text { с примесью } \\
\text { органики, } \\
\text { значительно } \\
\text { ожелезнен- } \\
\text { ный }\end{array}$ & $10 \%$ & $\begin{array}{l}1,5 \text { мм } \\
\text { редко } 2 \\
\text { мм }\end{array}$ & $8-10 \%$ & $-11-$ \\
\hline 12 & $\begin{array}{l}\text { Халвай-3. } \\
\text { Яма 5, } \\
\text { образец } \\
\text { шлиф } 2\end{array}$ & $\begin{array}{l}\text { менее } 0,01- \\
50 \% \\
0,01-0,1-20 \% \\
0,1-0,25-7 \% \\
0,25-0,5-10 \% \\
0,5-1,0-5-10 \% \\
1,0-1,5-3 \%\end{array}$ & $\begin{array}{l}\text { кварц - 40\% } \\
\text { магнетит, гематит - } \\
\text { до 28\% } \\
\text { гидроокислы желе- } \\
\text { за обломки сланцев } \\
\text { - до 20\% } \\
\text { полевые шпаты - } \\
10-12 \%\end{array}$ & $-11-$ & $-11-$ & $10-12 \%$ & $\begin{array}{l}\text { до } 1 \text { мм } \\
\text { редко } 1,5 \\
\text { х } 0,5 \text { мм }\end{array}$ & до $10 \%$ & $-11-$ \\
\hline 13 & $\begin{array}{l}\text { Халвай-3. } \\
\text { Яма 9, } \\
\text { образец } \\
\text { шлиф } 1\end{array}$ & \begin{tabular}{|l} 
менее $0,01-$ \\
$43 \%$ \\
$0,01-0,1-18 \%$ \\
$0,1-0,25-15 \%$ \\
$0,25-0,5-8 \%$ \\
$0,5-1,0-7 \%$ \\
$1,0-1,5-8 \%$ \\
$1,5-2,0-$ - до 1\%
\end{tabular} & $\begin{array}{l}\text { кварц - 60\% } \\
\text { полевые шпаты } \\
\text { - зн } \\
\text { обломки слюдистых } \\
\text { и кремнисто-слюди- } \\
\text { стых сланцев - до } \\
\text { 35\% } \\
\text { обломки кварцитов, } \\
\text { эпидот, рудные, } \\
\text { магнетит, гематит } \\
\text { - до 5\% }\end{array}$ & $\begin{array}{l}\text { глина +дресва } \\
\text { + органика } \\
\text { фоссратного со- } \\
\text { става (в шамоте } \\
\text { обломки слюди- } \\
\text { стых сланцев и } \\
\text { кварцитов) }\end{array}$ & $\begin{array}{l}\text { гидрослюды с } \\
\text { примесью гли- } \\
\text { ны и органики; } \\
\text { значительное } \\
\text { ожелезнение } \\
\text { в участках }\end{array}$ & до $10 \%$ & $\begin{array}{l}\text { до } 1-1,5 \\
\text { мм часто } \\
\text { встреча- } \\
\text { ется } 0,75 \\
\text { мм }\end{array}$ & до $10 \%$ & $\begin{array}{l}\text { органика } \\
\text { фосфатного } \\
\text { состава }\end{array}$ \\
\hline 14 & $\begin{array}{l}\text { Халвай-3. } \\
\text { Яма 9, } \\
\text { образец } \\
\text { шлиф } 3\end{array}$ & $\begin{array}{l}\text { менее } 0,01-45 \% \\
0,01-0,1-20 \% \\
0,1-0,25-10 \% \\
0,25-0,5-10 \% \\
0,5-1,0-5 \% \\
1,0-1,5-5 \% \\
1,5-2,0-5 \%\end{array}$ & $\begin{array}{l}\text { кварц }-60 \% \\
\text { полевые шпаты } \\
-3 \text { н }\end{array}$ & $-11-$ & $-11-$ & до 20\% & $\begin{array}{l}\text { до } 5 \times 1 \\
\text { мМ }\end{array}$ & до $10 \%$ & $-11-$ \\
\hline
\end{tabular}




\begin{tabular}{|c|c|c|c|c|c|c|c|c|c|}
\hline 15 & $\begin{array}{l}\text { Халвай-3. } \\
\text { Яма 9, } \\
\text { образец } \\
\text { шлиф } 4\end{array}$ & $\begin{array}{l}\text { менее } 0,01- \\
50 \% \\
0,01-0,1-30 \% \\
0,1-0,25-3 \% \\
0,25-0,5-3 \% \\
0,5-1,0-4 \% \\
1,0-1,5-10 \%\end{array}$ & $\begin{array}{l}\text { кварц - до 70\% } \\
\text { полевые шпаты } \\
\text { - 15\% } \\
\text { остальное: карбона- } \\
\text { ты, гидроокислы } \\
\text { железа, гематит, } \\
\text { магнетит }\end{array}$ & $-11-$ & $-1 /-$ & до $10 \%$ & $\begin{array}{l}\text { до } 1 \text { мм, } \\
\text { редко } 2 \\
\text { мм }\end{array}$ & до $8 \%$ & $\begin{array}{l}\text { - // - } \\
\text { органика с } \\
\text { примесью } \\
\text { карбоната }\end{array}$ \\
\hline 16 & $\begin{array}{l}\text { Халвай-3. } \\
\text { Яма 9, } \\
\text { образец } \\
\text { шлиф } 5\end{array}$ & $\begin{array}{l}\text { менее } 0,01 \\
0,01-0,1-50 \% \\
0,1-0,25-15 \% \\
0,25-0,5-15 \% \\
0,5-1,0-15 \% \\
1,0-1,5-5 \%\end{array}$ & $\begin{array}{l}\text { кварц - } 60 \\
\text { плагиоклазы - } \\
\text { магнетит, гематит } \\
-10 \% \\
\text { кварцитовидные } \\
\text { обломки пород }\end{array}$ & $\begin{array}{l}\text { - // - } \\
\text { в составе } \\
\text { дресвы обломки } \\
\text { гидрослюды } \\
\text { железистые } \\
\text { талькового } \\
\text { состава }\end{array}$ & $\begin{array}{l}\text { цемент } \\
\text { аналогичен } \\
\text { как в образце } \\
1 \text { ямы } 9\end{array}$ & до 5-6\% & $\begin{array}{l}\text { до } 1- \\
1,5 \text { мм, } \\
\text { редко до } \\
2,5 \text { мм }\end{array}$ & $\begin{array}{l}\text { до } 8 \text { - } 9 \\
\text { мМ }\end{array}$ & $\begin{array}{l}\text { - // - } \\
\text { состав органи- } \\
\text { ки карбонат- } \\
\text { фосфатный }\end{array}$ \\
\hline 17 & $\begin{array}{l}\text { Халвай-3. } \\
\text { Яма 9, } \\
\text { образец } \\
\text { шлиф } 6\end{array}$ & $\begin{array}{l}\text { менее } 0,01- \\
50 \% \\
0,01-0,1-30 \% \\
0,1-0,25-3 \% \\
0,25-0,5-3 \% \\
0,5-1,0-4 \% \\
1,0-1,5-10 \% \\
1,5-2,0-3 \mathrm{H}\end{array}$ & $\begin{array}{l}\text { кварц - до 60\% } \\
\text { полевые шпаты - } \\
\text { гематит, магнетит } \\
\text { - до 1\% }\end{array}$ & $\begin{array}{l}\text { глина + дресва } \\
\text { + органика } \\
\text { фосфатно- } \\
\text { карбонатная } \\
\text { (в слюдистых } \\
\text { обломках) в со- } \\
\text { ставе дресвы }\end{array}$ & $\begin{array}{l}\text { гидрослюда } \\
\text { значительно } \\
\text { ожелезненная }\end{array}$ & $10-12 \%$ & $\begin{array}{l}\text { до } 3,0 \text { мм } \\
\text { и } \\
\text { очень } \\
\text { редко до } \\
5,00\end{array}$ & до 10\% & $\begin{array}{l}\text { состав органи- } \\
\text { ки карбонат- } \\
\text { фосфатный } \\
\text { материя очень } \\
\text { тонкая }\end{array}$ \\
\hline
\end{tabular}

\section{TECHNICAL AND TECHNOLOGICAL ANALYSIS OF CERAMICS SINTASHTA OF THE KURGAN HALVAY 3}

\section{(C) 2015}

I.V. Shevnina, the scientific employee of laboratory of archeological researches Kostanay of the State University, Kostanay (Kazakhstan)

Annotation. The article is devoted to technical and technological analysis of pottery Sintashta kurgan Halvay 3. Kurgan Halvay 3 located on the left bank of the Tobolsk sleeves Karatamar reservoir (Kostanay, North Kazakhstan), was investigated during the 2009-2010 field seasons of Turgay archaeological expedition. Diameter of $32 \mathrm{~m}$ including construction ditch embankment height of $1 \mathrm{~m}$. Materials of the kurgan Halvay 3 belong to different archaeological periods, but the kurgan was built in Sintashta era. There were investigated eighteen vessels from five wells Sintashta (№1,3,6,8,9) and moat. Technical and technological analysis of raw materials and ceramic molding compounds was carried out using the method of binocular microscopy and petrography analysis. The feedstock used ferruginated hydromica clay. For kneading the clay dough recipe used two molding composition: clay + gravel + gruss manure; clay + gravel. Among technological methods in the manufacture of vessels recorded the use of bottom-capacitive, capacitive starting, spiral zone, lumpy patchwork, flaps, harnesses and pattern. Ceramics of the kurgan Halvay 3 (recipes molding compounds, processing methods in the manufacture of vessels) is directly analogous to those Sintashta monuments of the Southern Urals as settlement Arkaim, Ustie and burial Bolshekaragansky.

Keywords: Sintashta monuments, kurgan Halvay 3, Sintashta ceramics, technical and technological analysis Sintashta ceramics. 